\title{
Prevalence of hyperlipoproteinaemias in a random sample of men and in patients with ischaemic heart disease
}

\author{
M. C. Stone and T. B. S. Dick \\ From the Clinical Research Unit, Leigh Infirmary, Leigh, Lancs.
}

Lipoprotein patterns were estimated by membrane filtration and nephelometry in a random sample of men aged 30 to 69 years and in an age-matched group of male patients with ischaemic heart disease. The lipoprotein patterns were classified according to the SML classification.

Significantly abnormal lipoprotein patterns were found in 20 per cent of the random sample and 40 per cent of the ischaemic heart disease group. Five types of abnormal $S M L$ profile were found $(S, S M, M S, M$, and $M L)$, which corresponded to Fredrickson types $I I a, I I b, I V$, and $V$. The frequency distribution of these patterns was not significantly different in the random sample and ischaemic heart disease group.

Type IV hyperlipoproteinaemias $(M+M L$ types) comprised 53 per cent of all abnormal patterns in the random sample and 57 per cent in the ischaemic heart disease group. Thirty-one per cent of abnormal patterns in both the random sample and ischaemic heart disease group were Type IIa (S type), and about I2 per cent of abnormal patterns in each group had an increased concentration of both $S_{\mathrm{f}} 0-20$ and $S_{\mathrm{f}} 20-400$ lipoproteins, Type IIb (SM+MS types).

In the random sample, Type IV hyperlipoproteinaemias were significantly more common in obese than in slim men, whereas in the ischaemic heart disease group there was a smaller non-significant difference between them. However, slim ischaemic heart disease patients had a 3 times greater prevalence of abnormal lipoprotein patterns compared with slim random sample subjects.

In recent years the diagnosis of hyperlipidaemia has been rationalized by resolving hypercholesterolaemias and hypertriglyceridaemias into one of six types of abnormal lipoprotein pattern (Fredrickson, Levy, and Lees, 1967; World Health Organization, 1970). Studies have been conducted in patients with genetically determined hyperlipoproteinaemias (Fredrickson et al., 1968), but the prevalence of the various types of abnormal pattern in different populations is virtually unknown, and there are, as yet, few studies in subjects with ischaemic heart disease.

In this paper we report the use of a simple, inexpensive method of lipoprotein analysis, i.e. membrane filtration and nephelometry (Stone and Thorp, I966; Stone et al., I970), to estimate the prevalence and distribution of abnormal lipoprotein patterns in a sample of U.K. men aged 30 to 69 years and in an age-matched group of patients with ischaemic heart disease.

Received 9 April 1973.

\section{Subjects}

The subjects of this investigation were 429 men aged 30 to 69 years from the industrial town of Leigh, Lancashire, and from the immediate surrounding area. Two groups of subjects were examined, (I) a general practice random sample and (2) a group of patients with ischaemic heart disease.

\section{I) General practice random sample}

A U.K. 'general practice' consists of people who have placed themselves under the care of a specific general practitioner in the area in which they live and have 'registered' this fact with the National Health Service administration for the area. A record envelope within which are recorded details of any illness suffered by the subject is held in the record files of their general practitioner. The record is sent to him when he first accepts responsibility for the subject, even though the latter may not suffer from any illness and may not even consult him.

Our sample was taken from a general practice of about 
2,800 subjects who had 'registered' with one of us (M.C.S.). The 'practice' had been under the care of this same general practitioner for 16 years at the time the study was begun. Alternate record envelopes were selected and marked at a single session from the complete record files of the practice; thereby a I in 2 sample of the practice records was obtained.

The records of those subjects who had not reached their 15 th birthday on the day of selection were rejected, leaving 480 men and 534 women. All subjects were invited by letter, and later by personal interview, to take part in the study, part of which is reported here and part elsewhere (Stone et al., 1971 ; Dick and Stone, 1973).

In the male group there were 322 subjects in the 30 to 69 year age range. Only 283 of these subjects $(88 \%)$ completed the standardized examination, which is described elsewhere (Dick and Stone, 1973). Of the 39 subjects who were not examined, 21 refused examination, 13 left the area, and 5 died before they could be examined. The proportion of the subjects examined was about the same in each decade of age, the highest being 91 per cent in the 30 to 39 year group and the lowest 86 per cent in the 40 to 49 year group. The 283 subjects who completed the examination constitute the 'random sample' reported in this paper.

Clearly, a general practice sample is not necessarily representative of the entire population. However, in men the degree to which the sample represents the whole U.K. male population can be assessed by comparing the frequency distribution of 16 socioeconomic groups (General Register Office, 1966) in the sample, with that found in the 1966 U.K. sample census (General Register Office, 1969). These socioeconomic groups are reported in some of the census tables as 7 categories. We have compared the frequency distribution of these 7 categories in all men aged 15 years and over in our sample with that in the I966 U.K. sample census by calculation of $\chi^{2}$ on the original numbers. We found no significant difference $(P>0 \cdot$ IO $)$ between the distributions.

The sample, as would be expected, contained some subjects with diseases known to their general practitioner and others in whom abnormalities were discovered at examination. For example, 2 subjects were known to have diabetes mellitus. One (aged 36 years) was receiving insulin and the other (aged 6I years) was on diet alone. Both were well controlled and had normal lipoprotein patterns at the time of examination. One patient aged 59 years had suffered from myxoedema but was well controlled on $0.3 \mathrm{mg} /$ day of L-thyroxine sodium; he had a mild $\mathrm{S}$ type lipoprotein pattern at the time of examination.

Twenty-six of the subjects in the random sample $(9 \cdot 2 \%)$ had well-documented ischaemic heart disease. Eight of these had angina pectoris and 18 had survived a myocardial infarction. Only one of these patients was in the 30 to 39 year age range, 3 were aged 40 to 49 years, II were 50 to 59 years old, and II were between 60 and 69 years. Five of these 26 patients had 'mild hyperlipoproteinaemia' and a further 6 had 'significantly abnormal' lipoprotein patterns, as defined later in this paper.

A further 8 subjects were apparently well at the time of the examination but had electrocardiographic abnormalities classified as definite or probable ischaemic heart disease (Dick and Stone, 1973), and 4 further subjects had suffered episodes of severe central chest pain, but no electrocardiographic or enzyme changes had occurred at the time of the attack. None of these 12 subjects had significantly abnormal lipoprotein patterns at the time of their examination. Data from the random sample reported in this paper include all of these subjects.

\section{2) Male patients with ischaemic heart disease}

This group did not include any subjects from the random sample. It consisted of 146 subjects, Io9 of whom had survived a myocardial infarction and 37 who were suffering from angina pectoris. None of these patients was suffering from diabetes mellitus. Those with myocardial infarction had been treated in hospital by one of us (T.B.S.D.), during the acute episode, and were reexamined more than 3 months later. Only subjects with definite evidence of myocardial infarction were included in this group, i.e. they had a typical history with a changing pattern in serial electrocardiograms (Dick and Stone, 1973). Enzyme studies had been carried out on all of them, but no one was included unless he also had characteristic serial electrocardiographic abnormalities.

Sixty-nine of the myocardial infarction patients were examined between 3 and 12 months after the acute episode, a further 25 between $I$ and 3 years, and 15 between 3 and 12 years after infarction. All the patients who survived their myocardial infarctions for long enough to attend the medical outpatient clinic for surveillance, or who were referred to that clinic because of post-infarction angina, were examined in the Clinical Research Unit, i.e. all subjects available for examination are included.

After discharge from hospital each patient with myocardial infarction was advised to practise gradual mobilization within the limits of ordinary living. Fortyone subjects who were examined less than 6 months after infarction had been given no instructions as to diet and were not given any lipid-lowering drugs. Of the patients who were examined 6 months or more after the initial attack, some had lost weight at some time in the past, but their weight was stable at the time of their examination.

All of the 37 patients with angina pectoris had highly characteristic histories of praecordial pain on effort, assessed independently by each author, and had no history suggestive of myocardial infarction.

For at least 4 weeks before their lipoprotein analysis, all subjects in both the random sample and ischaemic heart disease groups had been on a 'normal' diet, were not losing weight, and were not taking any lipid-lowering medication.

\section{Methods}

Blood was drawn after a 14 -hour overnight fast, following at least 4 weeks on the subject's accustomed diet. The concentrations of the lipoprotein fractions were estimated from the results of 'MNC analysis' (mem- 
brane filtration, nephelometry, and cholesterol estimation).

\section{MNC analysis}

a) Serum total cholesterol (TC) was estimated by the method of Connerty, Briggs, and Eaton (I96r). The accuracy and reproducibility of the method is described elsewhere (Stone et al. 1970).

b) Membrane filtration and nephelometry were carried out by the method of Stone and Thorp (1966), as modified by Stone et al. (I970).

The concentrations of three lipoprotein fractions $S_{\mathrm{f}}$ 0-20 (beta lipoproteins), $\mathrm{S}_{\mathrm{f}}$ 20-400 (pre-beta lipoproteins), and $S_{\mathrm{f}}>400$ (chylomicrons) - were calculated from the nephelometric measurements and the value of TC, using the equations described by Stone et al. (I970, I97I), who have shown a high correlation between these estimated values and those obtained by analytical ultracentrifugation.

Subcapsular skinfold thickness ( $S S T$ ) was measured by the method of Tanner (1959) using a Harpenden skinfold caliper.

\section{Terminology and classification}

In an earlier publication (Stone et al., 197I) we have used the terms $S$ particles, $M$ particles, and $L$ particles to mean small, medium, and large low density lipoproteins, i.e. beta lipoproteins $\left(S_{\mathrm{f}} 0-20\right)$, pre-beta lipoproteins $\left(S_{\mathrm{f}}\right.$ 20-400), and chylomicrons $\left(S_{\mathrm{f}}>400\right)$, respectively. The types of lipoprotein pattern were determined from the concentrations of these 3 fractions and were defined as 'significantly abnormal' if the concentrations of one or more fractions exceeded the 99th percentile levels found in a group of 216 healthy young subjects (Stone et al., 1971) - mean age 23 years - none of whom is included in the present study. These lipoprotein concentrations which were called 'lower limits of significant abnormality', were at $550 \mathrm{mg} / 100 \mathrm{ml}$ for $S$ particles, $240 \mathrm{mg} / 100 \mathrm{ml}$ for $M$ particles, and 25 $\mathrm{mg} / \mathrm{I} 00 \mathrm{ml}$ for $\mathrm{L}$ particles in male subjects. We calculated that a significant abnormality in $\mathrm{S}$ particles could occur only if the serum cholesterol concentrations exceeded $270 \mathrm{mg} / 100 \mathrm{ml}$, and a significant abnormality in $M$ particles could occur only if the triglyceride concentrations exceeded $200 \mathrm{mg} / \mathrm{I} 00 \mathrm{ml}$.

In the present paper we have divided this 'significantly abnormal' group into 'moderately severe' and 'severe' as shown in the Fig. The cutting points between these degrees of abnormality $(700 \mathrm{mg} / 100 \mathrm{ml}$ and 500 $\mathrm{mg} / 100 \mathrm{ml}$ for $S$ and $M$ particles, respectively) were chosen so that a severe $S$ type pattern would require a minimum cholesterol concentration of about $350 \mathrm{mg} / \mathrm{ro0}$ $\mathrm{ml}$, and a severe $M$ type pattern a minimum triglyceride concentration of about $400 \mathrm{mg} / 100 \mathrm{ml}$ (i.e. about twice as great as the minimum level required for entry into the 'moderately severe' $M$ type category).

We also described (Stone et al., 1971) a 'boundary zone' abnormality in lipoprotein concentrations, between the $95^{\text {th }}$ and 99 th percentile levels for the young healthy

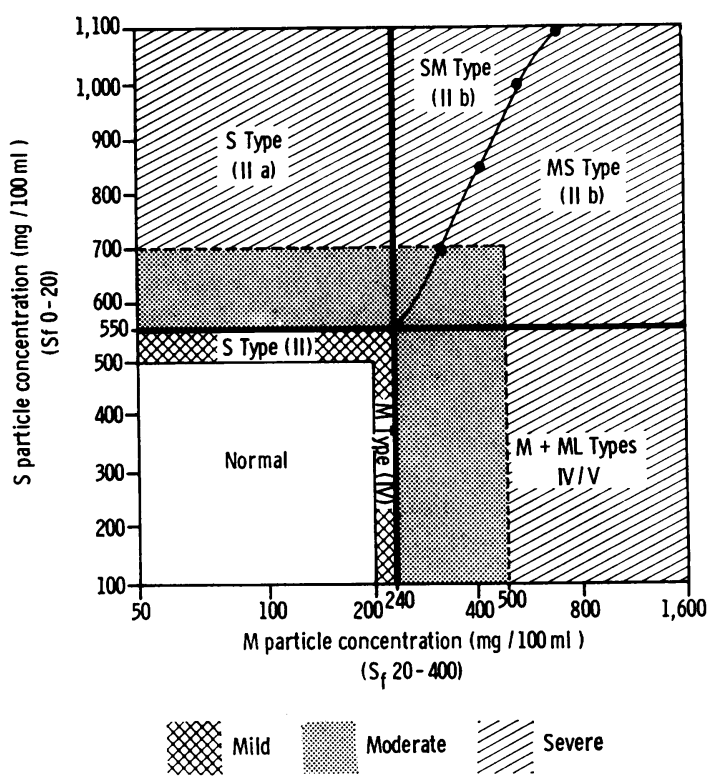

FIG. Terminology and concentration limits for each of the 5 types of abnormal lipoprotein pattern encountered in this study. The probable terminology in the WHO recommended classification is given in parentheses. The dividing line between the SM and $M S$ types was found by joining the concentrations of $S$ and $M$ particles having the same 'particle score' as described elsewhere (Stone et al., 1971).

reference group. This degree of abnormality is referred to in the present paper as 'mild hyperlipoproteinaemia' (Fig.), and is defined by $\mathrm{S}$ particle concentrations between 500 and $550 \mathrm{mg} / 100 \mathrm{ml}$, or $\mathrm{M}$ particle concentrations between 200 and $240 \mathrm{mg} / \mathrm{ro0} \mathrm{ml}$. We have calculated that a 'mild' $S$ type pattern could occur only if the serum cholesterol concentration exceeded about 250 $\mathrm{mg} / \mathrm{roO} \mathrm{ml}$ and a 'mild' $M$ type pattern only if the triglyceride concentrations exceeded about $165 \mathrm{mg} / \mathrm{ro0} \mathrm{ml}$.

The 'SML classification' of lipoprotein patterns based on MNC analysis, and using the 95th and 99th percentile cut-off levels defined above, was described fully elsewhere (Stone et al., 1971). The abnormal lipoprotein patterns found in the present study were classified as described in the latter publication, but to simplify understanding of our results we have also converted the SML type patterns to the more familiar classification recommended in the recent World Health Organization memorandum (1970). In the latter publication abnormal lipoprotein patterns are numbered I, IIa, IIb, III, IV, and V, following the system described by Fredrickson et al. (1967). The relation between the SML and Fredrickson classifications has been discussed elsewhere (Stone et al., 197I) and is shown in the Fig. Difficulties in translating SML type patterns to the 
WHO recommended classification are discussed later. No examples of LM (Type I) or MIII (Type III) patterns were encountered in the present study, and these types are therefore not shown in the Fig.

We infer from the WHO memorandum that all SM type and the majority of MS type patterns (in which both $S_{f} 0-20$ and $S_{f} 20-400$ lipoproteins are increased) would be classified as Fredrickson Type IIb. Two of our ML type patterns (in which the $S_{f}>400$ lipoproteins exceeded $100 \mathrm{mg} / 100 \mathrm{ml}$ ) were classified as Type V.

\section{Results}

Prevalence of abnormal lipoprotein patterns Table I shows the mean concentrations of serum cholesterol and of $S_{f} 0-20, S_{f} 20-400$, and $S_{f}>400$ lipoproteins in the two groups of subjects. Because $S_{\mathrm{f}}$ 20-400 concentrations were very skewed, they were transformed to logarithms, and the calculations of means and standard deviations, and of the significance of differences between the groups, were performed on the logarithms. The concentrations are expressed as antilogarithms in Table $\mathrm{I}$. It can be seen from this Table that we found higher mean values of cholesterol and of $S_{f}, 0-20$ and $S_{f} 20-400$ lipoproteins in the ischaemic heart disease group than in the random sample, and that the differences were greatest in the younger subjects.

Table 2 shows the prevalence of 'mild' and 'moderate + severe' hyperlipoproteinaemias. The Table shows that the ischaemic heart disease group had a significantly greater prevalence of both Type II a and Type IV patterns compared to the random sample. The age distribution of the random sample and ischaemic heart disease groups was similar $(49 \cdot 3 \pm 10 \cdot 4$ SD v $51 \cdot 9 \pm 8 \cdot 3 \mathrm{SD}$, respectively). In the random sample no significant relation was found between age and the overall presence of hyperlipoproteinaemias, though there was a trend towards increased prevalence in the 40 to 49 year age group. In the ischaemic heart disease group, however, the hyperlipoproteinaemia prevalence was significantly greater in the 30 to 39 -year-old group (8 of 10 patients) than in the 60 to 69 -year-old group (8 of 30 patients) $-P<0.05$. The prevalence of the various types of hyperlipoproteinaemia reported by other authors using electrophoresis and chemical analysis is summarized in Table 3 for comparison with our results shown in Table 2 . Though abnormal patterns were twice as common in the ischaemic heart disease group as in the random sample, the frequency distribution of the various types of pattern was not significantly different (Table 4).

Only 19 of the 429 subjects in this study $(4.4 \%)$ had 'severe' hyperlipoproteinaemia (Fig.). There were 9 subjects $(3.2 \%)$ in the random sample (I Type IIa, 2 Type IIb, 4 Type IV, and 2 Type V patterns), and IO patients $(6.8 \%)$ in the ischaemic heart disease group ( 3 Type IIa, 2 Type IIb, and 5 Type IV patterns). None of these subjects had tendon xanthomas. Though the prevalence of severe hyperlipoproteinaemia was twice as great in the ischaemic heart disease group as in the random sample, this difference was not significant at the 5 per cent level.

There were 63 subjects with moderate or severe $M$ or ML type patterns (corresponding to Type IV),

TABLE I Mean concentrations of serum cholesterol and $S, M$, and $L$ particle fractions

\begin{tabular}{|c|c|c|c|c|c|c|c|c|c|c|}
\hline \multirow{3}{*}{$\begin{array}{l}\text { Age } \\
\text { range } \\
(y r)\end{array}$} & \multicolumn{2}{|c|}{ No. of subjects } & \multicolumn{8}{|c|}{ Lipid and lipoprotein concentrations $(\mathrm{mg} / \mathrm{I} O 0 \mathrm{ml}) \pm S D$} \\
\hline & \multirow{2}{*}{$\begin{array}{l}\text { Ran- } \\
\text { dom } \\
\text { sample }\end{array}$} & \multirow{2}{*}{$\begin{array}{l}\text { Ischaemic } \\
\text { heart } \\
\text { disease }\end{array}$} & \multicolumn{2}{|c|}{$\begin{array}{l}\text { Serum cholesterol } \\
(\mathrm{mg} / \mathrm{IOO} \mathrm{ml})\end{array}$} & \multicolumn{2}{|l|}{$\begin{array}{l}S \text { particles } \\
\left(S_{f} 0-20\right)\end{array}$} & \multicolumn{2}{|l|}{$\begin{array}{l}M \text { particles } \$ \\
\left(S_{f} 20-400\right)\end{array}$} & \multicolumn{2}{|c|}{$\begin{array}{l}L \text { particles } \\
\left(S_{f}>400\right)\end{array}$} \\
\hline & & & $\begin{array}{l}\text { Random } \\
\text { sample }\end{array}$ & $\begin{array}{l}\text { Ischaemic } \\
\text { heart } \\
\text { disease }\end{array}$ & $\begin{array}{l}\text { Random } \\
\text { sample }\end{array}$ & $\begin{array}{l}\text { Ischaemic } \\
\text { heart } \\
\text { disease }\end{array}$ & $\begin{array}{l}\text { Random } \\
\text { sample }\end{array}$ & $\begin{array}{l}\text { Ischaemic } \\
\text { heart } \\
\text { disease }\end{array}$ & $\begin{array}{l}\text { Random } \\
\text { sample }\end{array}$ & $\begin{array}{l}\text { Ischaemic } \\
\text { heart } \\
\text { disease }\end{array}$ \\
\hline $30-39$ & 61 & IO & $2 \mathrm{II} \pm 52 \cdot \mathrm{I}$ & $260 \pm 74 \cdot 9^{\star}$ & $40 \mathrm{r} \pm 89 \cdot 0$ & $498 \pm 163 \cdot 6$ & $\begin{array}{r}+132.6 \\
121-63.4 \\
+178.9\end{array}$ & $\begin{array}{r}+114.5^{\star} \\
184-70.5 \\
+145.2 \dagger\end{array}$ & $9 \pm 18 \cdot 2$ & $8 \pm 8 \cdot 1$ \\
\hline $40-49$ & 84 & $5 \mathrm{I}$ & $223 \pm 49 \cdot 0$ & $246 \pm 55 \cdot 5^{\star}$ & $425 \pm 93 \cdot I$ & $464 \pm I I 6 \cdot I^{\star}$ & $\begin{array}{r}125-73.6 \\
+\mathrm{I} 12 \cdot 2\end{array}$ & $\begin{array}{r}182-80 \cdot 8 \\
+140.8^{\star}\end{array}$ & $9 \pm 16 \cdot 5$ & $9 \pm 10.9$ \\
\hline $50-59$ & 82 & 55 & $223 \pm 44 \cdot 3$ & $244 \pm 53 \cdot 3^{\star}$ & $429 \pm 87 \cdot 2$ & $466 \pm 102 \cdot 5^{\star}$ & $\begin{array}{r}122-58.4 \\
+\quad 89.9\end{array}$ & $\begin{array}{r}160-74.9 \\
+95.9\end{array}$ & $8 \pm 13.6$ & $8 \pm 7 \cdot 5$ \\
\hline $\begin{array}{l}60-69 \\
\text { All } \\
\text { subjects }\end{array}$ & $\begin{array}{r}56 \\
283\end{array}$ & $\begin{array}{r}30 \\
146\end{array}$ & $\begin{array}{l}222 \pm 45 \cdot 4 \\
220 \pm 47 \cdot 8\end{array}$ & $\begin{array}{l}233 \pm 42 \cdot 4 \\
246 \pm 57 \cdot 7 \ddagger\end{array}$ & $\begin{array}{l}427 \pm 9 I \cdot 2 \\
42 I \pm 90 \cdot I\end{array}$ & $\begin{array}{l}448 \pm 86 \cdot I \\
469 \pm 120 \cdot 6 \ddagger\end{array}$ & $\begin{array}{r}126-52 \cdot 5 \\
+131 \cdot 5 \\
124-70 \cdot 0\end{array}$ & $\begin{array}{c}136-56.2 \\
+133.6 \ddagger \\
163-73.5\end{array}$ & $\begin{array}{l}6 \pm 4 \cdot 9 \\
8 \pm 14 \cdot 2\end{array}$ & $\begin{array}{l}6 \pm 5 \cdot 6 \\
8 \pm 8 \cdot 2\end{array}$ \\
\hline
\end{tabular}

$\star \mathrm{P}<0.05$

$+\mathrm{P}<0.01$.

$\ddagger \mathrm{P}<0.001$.

$\S$ After log transformation $-t$ test calculated from logarithms. 
TABLE 2 Prevalence of hyperlipoproteinaemias in 30-69-year-old men in random sample and ischaemic heart disease groups

\begin{tabular}{|c|c|c|c|c|c|}
\hline \multirow{2}{*}{\multicolumn{2}{|c|}{$\frac{\text { Type of hyperlipoproteinaemia }}{\text { Classification }}$}} & \multicolumn{2}{|c|}{ 'Mild' hyperlipoproteinaemias } & \multicolumn{2}{|c|}{ 'Moderate + severe' hyperlipoproteinaemias } \\
\hline & & \multirow{2}{*}{$\begin{array}{l}\text { Random sample } \\
(N=283) \\
(\%)\end{array}$} & \multirow{2}{*}{$\begin{array}{l}\text { Ischaemic heart } \\
\text { disease } \\
(N=146) \\
(\%)\end{array}$} & \multirow{2}{*}{$\begin{array}{l}\text { Random sample } \\
(N=283) \\
(\%)\end{array}$} & \multirow{2}{*}{$\begin{array}{l}\text { Ischaemic heart } \\
\text { disease } \\
(N=I 46) \\
(\%)\end{array}$} \\
\hline$S M L$ & $\begin{array}{l}\text { WHO } \\
\text { recommended }\end{array}$ & & & & \\
\hline $\mathrm{S}$ & $\mathrm{IIa}$ & $5 \cdot 0$ & II $\cdot 0^{\star}$ & 6.0 & $12 \cdot 4^{\star}$ \\
\hline$S M+M S$ & IIb & - & - & 2.5 & $4 \cdot 8$ \\
\hline $\mathrm{M}+\mathrm{ML}$ & IV & $8 \cdot 1$ & $4 \cdot I$ & 10.3 & $23.3 t$ \\
\hline ML $\ddagger$ & V & - & - & 0.7 & 0 \\
\hline \multicolumn{2}{|l|}{ Total } & $13 \cdot 1$ & $15 \cdot 1$ & 19.4 & $40.4 t$ \\
\hline
\end{tabular}

$\star P<0.05$.

$+\mathrm{P}<0.001$.

$\ddagger$ ML patterns in which the large particle concentration exceeded $100 \mathrm{mg} / 100 \mathrm{ml}$.

29 in the random sample and 34 in the ischaemic heart disease group. The serum cholesterol concentration was $<250 \mathrm{mg} / \mathrm{ro0} \mathrm{ml}$ in $37(58.7 \%)$, between 250 and $300 \mathrm{mg} / 100 \mathrm{ml}$ in $25(39.7 \%)$, and in one subject $(\mathrm{r} .6 \%)$ it exceeded $300 \mathrm{mg} / \mathrm{r} 00 \mathrm{ml}$. In the 40 to 59 -year-old subjects the mean serum cholesterol concentration was significantly higher in the Type IV patterns in the ischaemic heart disease group ( $255 \mathrm{mg} / 100 \mathrm{ml} \pm 25 \cdot \mathrm{I} \mathrm{SD}$ ) than in the random sample $(234 \pm 37 \cdot 2$ SD) $-\mathrm{P}<0.05$.
Two further random sample subjects had ML type patterns in which the $\mathrm{L}$ particle concentration exceeded $100 \mathrm{mg} / 100 \mathrm{ml}$, and were therefore considered to correspond to Type $\mathrm{V}$ patterns. Both of these subjects had hypercholesterolaemia (294 and $412 \mathrm{mg} / 100 \mathrm{ml})$.

\section{Hyperlipoproteinaemia and obesity}

We studied the relation between hyperlipoproteinaemia and subscapular skinfold thickness (SST) in

TABLE 3 Prevalence of hyperlipoproteinaemias in various studies (male subjects only)

\begin{tabular}{|c|c|c|c|c|c|c|c|c|c|c|}
\hline \multirow[t]{3}{*}{ Authors } & \multirow{3}{*}{$\begin{array}{l}\text { No. of } \\
\text { subjects }\end{array}$} & \multirow{3}{*}{$\begin{array}{l}\text { Age } \\
(y r)\end{array}$} & \multirow{3}{*}{\multicolumn{2}{|c|}{ Methods }} & \multirow{2}{*}{\multicolumn{2}{|c|}{$\begin{array}{l}\text { Cutting points } \\
\text { for upper limits } \\
\text { of normal } \\
(\mathrm{mg} / \mathrm{I00} \mathrm{ml})\end{array}$}} & \multicolumn{4}{|c|}{ Prevalence of hyperlipoproteinaemias } \\
\hline & & & & & & & \multirow{2}{*}{$\begin{array}{l}\text { Type II } \\
- \\
(\%)\end{array}$} & \multirow{2}{*}{$\begin{array}{l}\text { Type IV } \\
(\%)\end{array}$} & \multirow{2}{*}{$\begin{array}{l}\text { Type V } \\
(\%)\end{array}$} & \multirow{2}{*}{$\begin{array}{l}\text { All abnor- } \\
\text { mal patterns } \\
(\%)\end{array}$} \\
\hline & & & & & $\begin{array}{l}\text { Serum } \\
\text { choles- } \\
\text { terol }\end{array}$ & $\begin{array}{l}\text { Serum } \\
\text { trigly- } \\
\text { cerides }\end{array}$ & & & & \\
\hline $\begin{array}{c}\text { 'Normal' subjects } \\
\text { Werko (I97I) }\end{array}$ & 76 & 54 & $\begin{array}{l}\text { Electropl } \\
\text { plus li } \\
\text { analysi }\end{array}$ & oresis & $\star$ & $\star$ & $13 \cdot 0$ & $9 \cdot 0$ & $3 \cdot 0$ & $25 \cdot 0$ \\
\hline $\begin{array}{l}\text { Leren and Haabrekke } \\
\text { (I971a) } \\
\text { Wood et al. (1972) } \\
\text { Patterson and Slack }\end{array}$ & $\begin{array}{l}123 \\
494\end{array}$ & $\begin{array}{l}30-64 \\
25-79\end{array}$ & " & ", & $\begin{array}{l}275 \\
275\end{array}$ & $\begin{array}{l}200 \\
200\end{array}$ & $\begin{array}{r}26 \cdot 0 \\
2 \cdot 8\end{array}$ & $\begin{array}{r}4.0 \\
13.0\end{array}$ & $\overline{0.2}$ & $\begin{array}{l}30 \cdot 0 \\
17.8\end{array}$ \\
\hline (1972) & 107 & $20-79$ & 川 & , & $t$ & $t$ & 0.9 & $2 \cdot 8$ & 0.9 & $4 \cdot 6$ \\
\hline \multirow{3}{*}{$\begin{array}{l}\text { Ischaemic heart disease } \\
\text { Werko (197I) } \\
\text { Leren and Haabrekke } \\
\text { (197Ib) } ¥ \\
\text { Patterson and Slack } \\
\text { (1972) }\end{array}$} & 100 & 54 & " & 川 & $\star$ & $\star$ & $37 \cdot 0$ & $22 \cdot 0$ & 0 & $59 \cdot 0$ \\
\hline & 152 & $30-64$ & 川 & " & 275 & 200 & $6 \mathrm{I} \cdot 8$ & $13 \cdot 2$ & - & $75 \cdot 0$ \\
\hline & 107 & $20-79$ & ", & ", & $\dagger$ & $t$ & $\mathbf{1 2} \cdot \mathbf{I}$ & $10 \cdot 3$ & 一 & $22 \cdot 4$ \\
\hline
\end{tabular}

* Not given.

+ Lipid concentrations converted to 'scores' to allow for age and sex.

¥ Excluding 'acute myocardial infarction'. 
TABLE 4 Frequency distribution of different types of 'moderate + severe' hyperlipoproteinaemias

\begin{tabular}{|c|c|c|c|c|c|}
\hline \multirow{2}{*}{\multicolumn{2}{|c|}{$\begin{array}{l}\text { Type of } \\
\text { hyperlipoproteinaemia }\end{array}$}} & \multicolumn{4}{|c|}{ Frequency distribution } \\
\hline & & \multirow{2}{*}{\multicolumn{2}{|c|}{$\begin{array}{l}\text { Random sample } \\
\text { (55 abnormal } \\
\text { patterns) }\end{array}$}} & \multirow{2}{*}{\multicolumn{2}{|c|}{$\begin{array}{l}\text { Ischaemic heart } \\
\text { disease ( } 59 \text { ab- } \\
\text { normal patterns) }\end{array}$}} \\
\hline \multirow[t]{2}{*}{$S M L$} & \multirow{2}{*}{$\begin{array}{l}\text { WHO } \\
\text { recom- } \\
\text { mended }\end{array}$} & & & & \\
\hline & & No. & $\%$ & No. & $\%$ \\
\hline $\mathbf{S}$ & IIa & 17 & 30.9 & 18 & 30.5 \\
\hline$S M+M S$ & IIb & 7 & $12 \cdot 7$ & 7 & $11 \cdot 9$ \\
\hline$M+M L$ & IV & 29 & $52 \cdot 7$ & 34 & $57 \cdot 6$ \\
\hline$M L^{\star}$ & $\mathbf{V}$ & 2 & $3 \cdot 7$ & 0 & 0 \\
\hline \multicolumn{2}{|l|}{ Total } & 55 & $100 \cdot 0$ & 59 & $100 \cdot 0$ \\
\hline
\end{tabular}

$\star$ ML patterns in which the large particle concentration exceeded $100 \mathrm{mg} / 100 \mathrm{ml}$.

the random sample and in the ischaemic heart disease group. In each group subscapular skinfold thicknesses were placed in rank order in each decade of age. Subjects in the first and third tertile of SST in each age group formed the two groups shown in Table 5. Only slight differences were found in the range of SST in the corresponding tertiles of the random sample and ischaemic heart disease groups.

It can be seen from Table 5 that the prevalence of ' $S$ predominant' hyperlipoproteinaemias (i.e. those in which $\mathrm{S}_{\mathrm{f}} \mathrm{O}^{-20}$ is the predominant fraction Stone et al., 1971) was greater in obese than in slim random sample subjects, but this difference was not significant at the 5 per cent level. However, ' $M$ predominant' patterns (i.e. $M S+M+M L$ types the disorders of endogenous triglyceride transport) were significantly more common in obese than in slim subjects in the random sample, though not in the ischaemic heart disease group.
Table 5 also shows a highly significant increase in the prevalence of hyperlipoproteinaemias in slim ischaemic heart disease subjects compared to their slim random sample counterparts $(P<0.005)$. However, in the obese subjects no significant difference in prevalence was found.

\section{Hyperlipoproteinaemia in myocardial infarc- tion and angina pectoris}

Because of suggested differences in lipoprotein concentrations between myocardial infarction and angina (Pilkington and Koerselman, 196r), we examined the prevalence of hyperlipoproteinaemias in these groups separately. The results are shown in Table 6. The groups were similar in age and sub-

TABLE 6 Prevalence of hyperlipoproteinaemias in random sample and in patients with myocardial infarction and angina pectoris (men 30 to 69 years)

\begin{tabular}{|c|c|c|c|}
\hline $\begin{array}{l}\text { Type of } \\
\text { hyperlipoproteinaemia }\end{array}$ & $\begin{array}{l}\text { Random } \\
\text { sample } \\
(N=283) \\
(\%)\end{array}$ & $\begin{array}{l}\text { Myocardial } \\
\text { infarction } \\
(N=\text { Iog) } \\
(\%)\end{array}$ & $\begin{array}{l}\text { Angina } \\
\text { pectoris } \\
(N=37) \\
(\%)\end{array}$ \\
\hline $\begin{array}{l}\text { IIa }+ \text { IIb } \\
\text { IV }+ \text { V }\end{array}$ & $\begin{array}{r}8.5 \\
10.9\end{array}$ & $\begin{array}{l}20 \cdot 2 \dagger \\
22.0 \dagger\end{array}$ & $\begin{array}{c}8 \cdot 1 \\
27 \cdot 0+\end{array}$ \\
\hline Total & 19.4 & $42 \cdot 2 \ddagger$ & $35 \cdot I^{\star}$ \\
\hline $\begin{array}{l}\star P<0.05 . \\
\dagger P<0.01 . \\
\ddagger P<0.001 . \\
P \text { values indicate sigr } \\
\text { random sample. }\end{array}$ & $n$ & ence in & from \\
\hline
\end{tabular}

scapular skinfold thickness. Both of the ischaemic heart disease groups showed a significantly greater prevalence of Type IV hyperlipoproteinaemia compared to the random sample, but Types IIa $+\mathrm{IIb}$

TABLE 5 Prevalence of ' $S$ predominant' and ' $M$ predominant' hyperlipoproteinaemias in slim and obese subjects based on tertiles of subscapular skinfold thickness (SST)

\begin{tabular}{|c|c|c|c|c|c|c|}
\hline & \multicolumn{2}{|c|}{$\begin{array}{l}\text { 'S predominant' } \\
\text { hyperlipoproteinaemias } \\
(S+S M \text { types })\end{array}$} & \multicolumn{2}{|c|}{$\begin{array}{l}\text { 'M predominant' } \\
\text { hyperlipoproteinaemias } \\
(M S+M+M L \text { types })\end{array}$} & \multicolumn{2}{|c|}{$\begin{array}{l}\text { All hyperlipo- } \\
\text { proteinaemias }\end{array}$} \\
\hline & $\begin{array}{l}\text { Slim } \\
\text { tertile } \\
(\%)\end{array}$ & $\begin{array}{l}\text { Obeset } \\
\text { tertile } \\
(\%)\end{array}$ & $\begin{array}{l}\text { Slim } \\
\text { tertile } \\
(\%)\end{array}$ & $\begin{array}{l}\text { Obese } \\
\text { tertile } \\
(\%)\end{array}$ & $\begin{array}{l}\text { Slim } \\
\text { tertile } \\
(\%)\end{array}$ & $\begin{array}{c}\text { Obese } \\
\text { tertile } \\
(\%)\end{array}$ \\
\hline $\begin{array}{l}\text { Random sample ( } 98 \text { subjects per tertile) } \\
\text { Ischaemic heart disease patients ( } 48 \text { subjects per tertile) }\end{array}$ & $\begin{array}{r}3 \cdot 4 \\
12 \cdot 5\end{array}$ & $\begin{array}{r}9 \cdot 0 \\
16 \cdot 7\end{array}$ & $\begin{array}{r}5 \cdot 6 \\
16 \cdot 7\end{array}$ & $\begin{array}{l}24 \cdot 7 \ddagger \\
31 \cdot 2\end{array}$ & $\begin{array}{r}9 \cdot 0 \\
29 \cdot 2\end{array}$ & $\begin{array}{l}33 \cdot 75 \\
47 \cdot 9\end{array}$ \\
\hline
\end{tabular}


patterns were more common only in the myocardial infarction group. However, with the small number of cases of angina pectoris available, the difference in hyperlipoproteinaemia distribution between the two ischaemic heart disease groups was not statistically significant.

\section{Discussion}

In this study we found 'moderate and severe' lipoprotein patterns in about 20 per cent of men in a random sample and in 40 per cent of an agematched ischaemic heart disease group. We also found 'mild' hyperlipoproteinaemias in a further 13 per cent of the random sample and 15 per cent of the ischaemic heart disease group. The frequency distribution of the 5 types of abnormal SML profile was similar in the two groups (Table 4). About 30 per cent of abnormal patterns corresponded to Type IIa, about 12 per cent to Type IIb, and about 55 per cent to Type IV. We found only 2 possible Type $\mathrm{V}$ patterns, both of which were in the random sample, i.e. about 3 per cent of the abnormal patterns in that group.

Our random sample was drawn from a single general practice and could therefore be criticized on the grounds that it is not representative of U.K. men as a whole. However, our data suggest that in terms of socioeconomic groups, it is in fact a reasonably representative sample.

We have deliberately not excluded from our random sample those subjects with known or suspected ischaemic heart disease since one of our aims was to estimate the prevalence and distribution of hyperlipoproteinaemias in a population sample. We have, however, recalculated the prevalences after excluding these subjects and found virtually no differences compared with the results published in our tables.

There are certain difficulties in making valid comparisons between our results and those summarized in Table 3. The 4 studies summarized in that Table differ from our own in methodology, age range, and age distribution of the subjects, and (with the exception of the study of Patterson and Slack, 1972) in country of origin. Leren and Haabrekke (I971a) and Wood et al. (1972) used similar cutting points to our own (in terms of cholesterol and triglyceride levels) and made no adjustment for age, whereas Patterson and Slack (1972) used higher cutting points and transformed lipid concentrations to 'scores' to allow for age and sex. The prevalence reported by the latter authors is therefore understandably lower than the other results shown in Table 3.

Despite these differences, the prevalence of hyperlipoproteinaemias in 'normals' in the first 3 studies summarized in Table $3(18-30 \%)$ is similar to that in our random sample ( $19 \%$ ), and the ratio, IHD prevalence 'normal' prevalence in the studies of Werko (197I) and Leren and Haabrekke (1971a, b), (2.4 and 2.5, respectively), is similar to our own (2.1). However, the difference in hyperlipoproteinaemia prevalence between our random sample and ischaemic heart disease groups is less than that reported by Heinle et al. (1969) between patients with angiographically determined coronary artery disease and those with normal coronary arteries $(54 \%$ and II $\%$ respectively), or by Patterson and Slack (1972) who found 22.4 and 4.6 per cent in ischaemic heart disease and controls, respectively.

It can be seen from Table 3 that studies in which electrophoresis and chemical estimation of cholesterol and triglycerides have been used differ from one another in the proportion of patterns assigned to Types II and IV, despite the use of similar 'upper limits of normal'. This difference could be ascribed in part to true population variation, but it seems probable that there are also some differences between the studies in the classification of lipoprotein patterns.

Our own data can be compared with these earlier results only if it is accepted (as shown elsewhere Stone et al., 1971), that the W.H.O. recommended terminology can be applied with some confidence to SML type patterns. However, it is difficult to ascribe some MS type patterns to the Type IIb category, especially those in which the co-ordinates of $S$ and $M$ particle concentrations place the pattern in the right lower region of the MS area shown in the Fig. Such patterns appear to us to have more in common with Type IV than with Type II hyperlipoproteinaemia and since the lipoprotein distribution is dominated by the $S_{f} 20-400$ fraction, we include MS type patterns in the ' $M$ predominant' group (Table 5).

If, for the purposes of comparison with the data in Table 3, we assign all MS type patterns to Type $\mathrm{IIb}$, and the $2 \mathrm{ML}$ type patterns in which the $\mathrm{L}$ particle concentration exceeds $100 \mathrm{mg} / 100 \mathrm{ml}$, to Type V, then the prevalence of Type II hyperlipoproteinaemia in the present study was 8.5 per cent, that of Type IV r0.2 per cent, and Type V 0.7 per cent. Similarly, in our ischaemic heart disease group the prevalence of Type II was $17 \cdot 2$ and Type IV 23.3 per cent; there were no Type V patterns in our ischaemic heart disease group.

The relation which we found between obesity and lipoprotein concentrations (particularly $M$ particles) was to be expected, since it has been shown in a prospective study (Harlan, Graybiel, and Osborne, 1965) that the concentration of $S_{f}$ 12-400 lipoproteins increased in subjects who gained weight. 
However, the greater prevalence of $M$ predominant hyperlipoproteinaemia associated with ischaemic heart disease, cannot be attributed to obesity, since slim subjects with ischaemic heart disease had a three times greater prevalence of $M$ predominant patterns than slim random sample subjects.

We found a low prevalence of severe hyperlipoproteinaemias in both random sample and ischaemic heart disease groups, for example, only 0.4 per cent of the random sample and 2.7 per cent of the ischaemic heart disease group had severe Type II patterns, with serum cholesterol concentrations greater than $350 \mathrm{mg} / 100 \mathrm{ml}$. It has been shown (Slack, 1969) that men with genetically determined Type II hyperlipoproteinaemia have a greater risk of premature myocardial infarction and death than those with Types III, IV, and V. However, our random sample data suggest that the prevalence of such severe Type II patterns in U.K. men is very low.

In a prospective study, Kannel et al. (I97I) found that the majority of hypercholesterolaemias which predisposed to coronary disease in the population were in the moderate range 250 to $350 \mathrm{mg} / 100 \mathrm{ml}$. However, hypercholesterolaemia is found with various types of abnormal lipoprotein pattern each of which may indicate a different underlying disorder of lipid transport or metabolism. In the present study all subjects with 'mild' and 'moderate' Type II a + IIb patterns had serum cholesterol concentrations between 250 and $350 \mathrm{mg} / 100 \mathrm{ml}$, as did $2 \mathrm{I}$ per cent with 'mild' and 43 per cent with 'moderate + severe' Type IV/V patterns.

On the basis of the publications shown in Table 3 it appears difficult to compare the prevalence of different types of hyperlipoproteinaemia in population samples, even when the same method (e.g. electrophoresis) and the same cutting points for lipids are used. Our use of a different method of analysis and classification may at first sight appear to aggravate the situation. However, we justify our publication of these results on the grounds that (a) the method has been shown to provide reproducible analyses in different laboratories (Stone $e t$ al., 1970), (b) the data are expressed in quantitative terms, and (c) since the cutting points for each fraction are fixed, the SML classification of any particular sample is unequivocal. MNC analysis is now being used in a number of laboratories in different parts of the world; therefore our results should provide a basis for comparison with those populations.

We gratefully acknowledge research grants from the Medical Research Council (M.C.S.), the Manchester Regional Hospital Board (T.B.S.D.), and Imperial Chemical Industries Limited.

\section{References}

Connerty, H. V., Briggs, A. R., and Eaton, E. H. (I96I). Simplified determination of the lipid components of blood serum. Clinical Chemistry, 7, 37.

Dick, T. B. S., and Stone, M. C. (1973). Prevalence of three cardinal risk factors in random sample of men and in patients with ischaemic heart disease. British Heart Fournal, 35, 381.

Fredrickson, D. S., Levy, R. I., Kwiterovich, P. O., Jr., and Jover, A. (1968). The typing of hyperlipoproteinaemia - a progress report. In Advances in Experimental Medicine and Biology, Vol. 4, p. 307. Ed. by W. L. Holmes, L. A. Carlson, and R. Paoletti. Plenum Press, New York.

Fredrickson, D. S., Levy, R. I., and Lees, R. S. (1967). Fat transport in lipoproteins - an integrated approach to mechanisms and disorders. New England fournal of Medicine, 276, 34 .

General Register Office (1966). Classification of Occupations. Her Majesty's Stationery Office, London.

General Register Office (1969). Sample Census 1966, Great Britain Economic Activity Tables, Part III, p. 40I. Her Majesty's Stationery Office, London.

Harlan, W. R., Jr., Graybiel, A., and Osborne, R. K. (1965). Determinants of cardiovascular disease in a young population. American fournal of Cardiology, 15, 1 .

Heinle, R. A., Levy, R. I., Fredrickson, D. S., and Gorlin, R. (1969). Lipid and carbohydrate abnormalities in patients with angiographically documented coronary artery disease. American fournal of Cardiology, 24, 178.

Kannel, W. B., Castelli, W. P., Gordon, T., and McNamara, P. M. (I97I). Serum cholesterol, lipoproteins, and the risk of coronary heart disease. Annals of Internal Medicine, 74, I.

Leren, P., and Haabrekke, O. (1971a). Blood lipids in normals. Acta Medica Scandinavica, 189, 501.

Leren, P., and Haabrekke, O. (I97I $\mathrm{I}$ ). Blood lipids in patients with coronary heart disease. Acta Medica Scandinavica, 189, 505 .

Patterson, D., and Slack, J. (1972). Lipid abnormalities in male and female survivors of myocardial infarction and their first-degree relatives. Lancet, $\mathbf{1}, 393$.

Pilkington, T. R. E., and Koerselman, H. (I96I). Lipid patterns in myocardial infarction and angina pectoris. Lancet, I, rorg.

Slack, J. (1969). Risks of ischaemic heart-disease in familial hyperlipoproteinaemic states. Lancet, 2, 1380.

Stone, M. C., and Thorp, J. M. (1966). A new technique for the investigation of the low-density lipoproteins in health and disease. Clinica Chimica Acta, 14, 812.

Stone, M. C., Thorp, J. M., Mills, G. L., and Dick, T. B. S. (I970). Comparison of membrane filtration and nephelometry with analytical ultracentrifugation, for the quantitative analysis of low density lipoprotein fractions. Clinica Chimica Acta, 30, 809.

Stone, M. C., Thorp, J. M., Mills, G. L., and Dick, T. B. S. (I97I). Diagnosis and classification of abnormal lipoprotein patterns. Clinica Chimica Acta, 31, 333.

Tanner, J. M. (1959). The measurement of body fat in man. Proceedings of the Nutrition Society, 18, 148.

Werko, L. (1971). Can we prevent heart disease? Annals of Internal Medicine, 74, 278.

Wood, P. D. S., Stern, M. P., Silvers, A., Reaven, G. M., and Von Der Groeben, J. (1972). Prevalence of plasma lipoprotein abnormalities in a free-living population of the Central Valley, California. Circulation, 45, 114 .

World Health Organization (1970). Classification of hyperlipidaemias and hyperlipoproteinaemias. Bulletin of the World Health Organization, 43, 891.

Requests for reprints to Dr. M. C. Stone, Clinical Research Unit, Leigh Infirmary, Leigh, Lancashire. 